\title{
Civilisations
}

Revue internationale d'anthropologie et de sciences

humaines

61-1| 2012

Au-delà du consensus patrimonial

\section{African Heritage Design}

Entertainment Media and Visual Aesthetics in Ghana

\section{Marleen de Witte and Birgit Meyer}

\section{(2) OpenEdition}

12 Journals

Electronic version

URL: http://journals.openedition.org/civilisations/3132

DOI: 10.4000/civilisations.3132

ISSN: 2032-0442

\section{Publisher}

Institut de sociologie de l'Université Libre de Bruxelles

\section{Printed version}

Date of publication: 22 December 2012

Number of pages: $43-64$

ISBN: 2-87263-038-4

ISSN: 0009-8140

\section{Electronic reference}

Marleen de Witte and Birgit Meyer, «African Heritage Design », Civilisations [Online], 61-1 | 2012, Online since 30 December 2015, connection on 30 April 2019. URL : http://journals.openedition.org/

civilisations/3132 ; DOI : 10.4000/civilisations.3132

(c) Tous droits réservés 


\title{
African Heritage Design \\ Entertainment Media and Visual Aesthetics in Ghana ${ }^{1}$
}

\author{
Marleen DE WITTE and Birgit MEYER
}

\begin{abstract}
This paper explores the plurality and dynamics of 'cultural heritage' formation in Ghana by looking at key players in the historically constituted heritage arena and the contestations between them. Focusing on the intersecting domains of the state, religion, and entertainment media, it discerns several tendencies with regard to the framing of cultural pasts: mobilization of 'heritage' by the state as part of national identity politics; contestation of this state project by Pentecostal churches that view 'heritage' as demonic and dangerous; and revaluation of 'heritage' as aesthetic style in local television and video making. Recent, marketdriven trends towards a more positive representation of 'African heritage' depart from earlier state initiatives in their explicit focus on visual style and design, raising new questions about the links between heritage and visual aesthetics and asking for an understanding of cultural heritage that takes into account issues of style, design, and commerce.
\end{abstract}

Keywords: Ghana, heritage formation, Sankofaism, media, visual aesthetics, style.

Résumé : Prenant comme point de départ l'arène patrimoniale historiquement constituée au Ghana, et plus particulièrement les acteurs clés de cette arène et les conflits entre eux, les auteurs explorent la pluralité et les dynamiques de la construction du "patrimoine culturel" dans ce pays. Plusieurs domaines - État, religion, media de loisir - et tendances dans la construction du passé culturel se rencontrent : la mobilisation du 'patrimoine'par l'État dans le cadre des politiques d'identité nationale, la contestation de ce projet étatique par les Églises pentecôtistes qui considèrent le 'patrimoine' comme dangereux et satanique, et la valorisation $d u$ 'patrimoine' comme style esthétique dans les vidéos présentées par les télévisions locales. Les tendances économiques récentes visant à donner une image plus positive du 'patrimoine africain's'ancrent dans des initiatives publiques antérieures et s'appuient sur la notion de style et de design visuel. Ainsi, ces tendances posent de nouvelles questions sur les liens entre patrimoine et esthétique visuelle, et impliquent une compréhension du patrimoine culturel prenant en compte les questions de style, de design et de commercialisation.

Mots-clés : Ghana, construction du patrimoine, Sankofaism, media, esthétique visuelle, style.

1 This article is based upon research and discussions in the framework of the research project 'Heritage Dynamics: Politics of Authentication and Aesthetics of Persuasion in Brazil, Ghana, South Africa and the Netherlands' (Meyer, Roodenburg, and Van de Port 2008) which is generously sponsored by the Netherlands Organization for Scientific Research NWO. Birgit Meyer directs the program and Marleen de Witte is engaged as a postdoc researcher. We would like to thank Joël Noret and two anonymous reviewers for stimulating comments that helped us sharpen our points. 


\section{Introduction}

In contemporary Ghana 'cultural heritage' is a matter of fierce public debate and contestation, but also, and increasingly so, of entertainment and marketing. Long associated with state efforts to articulate a national culture, cultural heritage is now being mobilized in a multitude of ways and to a number of different ends, including commercial ones. ${ }^{2}$ Especially since the media liberalisation in the 1990 s that opened up the public sphere to a plurality of voices and images, a variety of actors put their designs of 'culture and tradition' out in the open to attract people to alternative heritage projects not necessarily linked to the nation. Whereas previously the state provided the hegemonic framework for the articulation of a national cultural heritage, this framework has come to face increasing public contestations from a number of societal groups, especially Pentecostal Christian ones. At the same time Ghanaian commercial media today address (and create) a growing, mainly urban market for 'African heritage' as a deliberate cultural style and entertainment.

The formation of heritage always involves processes of styling that vest 'culture and tradition' with an aesthetic appeal. Distinctive about the recent, market-driven trend towards a revaluation of heritage in the framework of entertainment media is the heavy emphasis placed on visual aesthetics (see also Brosius \& Polit 2001: 8-10; Probst 2011). In contemporary Ghana, current representations of heritage - visible in local television and video-movies, but also in fashion, beauty, music and other popular cultural expressions - depart from earlier state projects of national heritage formation in their overtly commercial nature and explicit focus on design and marketing. They are often inspired by globally circulating icons of 'African culture' as much as by local traditions. Heritage is thus formed in a plural discursive and aesthetic field, in which state officials, chiefs, ethnic activists, religious leaders and cultural entrepreneurs seek to convince audiences of the appeal of their versions of heritage while disclaiming others. This arena is increasingly constituted by electronic and digital media, and commercial in nature. In this article we examine the articulation between cultural heritage and electronic media in the culturally diverse setting of Ghana, where both of us have been doing ethnographic research on transformations in the field of media, culture, and religion. ${ }^{3}$

The politics of cultural heritage thrives on a salient paradox: while heritage refers to tangible and intangible repositories of value that feature as given resources for identity politics, much effort is put into the actual making of heritage. Heritage,

2 Sometimes the term 'heritage' is used to refer to the mobilization of objects, practices, and knowledge of the past; sometimes other terms such as 'tradition,' 'culture,' or 'ancestral knowledge' are used. In Ghana, such terms are part of a discursive field in which 'tradition,' 'culture' and 'heritage' are used more or less interchangeably and are imagined as rooted in a past before European contact.

3 Over the past twenty years, Meyer's work explored local appropriations of missionary Christianity and the appeal of Pentecostalism (Meyer 1998, 1999a), the rise of the Ghanaian video-film industry and the formation of a new public sphere in the era of neo-liberalization (Meyer 1999b, 2004). De Witte's work has examined the transformation of funeral practices (2001), the use of modern media by Pentecostal and neo-traditionalist groups (2008), and the emergence of new heritage styles in media. In our various research projects, the imagination of tradition as cultural heritage has been a recurrent theme. 
as Barbara Kirshenblatt-Gimblett pointed out, 'is a mode of cultural production in the present that has recourse to the past' (1998: 7). Heritage making includes the fashioning of particular items as heritage, politics of ownership and its concomitant dynamics of in- and exclusion, as well as modes of address and performance that facilitate or block recognition and appropriation (Meyer, Roodenburg, and Van de Port 2008).

Two aspects of heritage making require special attention. One, the construction of a cultural form as heritage does not necessarily or automatically yield its intellectual and emotional recognition and appropriation on the part of beholders. Especially in culturally and religiously diverse settings, the recognition of heritage on the part of those addressed is an intricate political process that deserves far more attention than it received so far (De Jong and Rowlands 2007). At stake is the capacity of a cultural form that is featured as heritage to capture those addressed by it. This entails not only a process of intellectual recognition, but also a sensational and emotional involvement through which heritage is incorporated as a part of one's social identity or, as is the case with regard to those contesting from a Pentecostal point of view the Ghanaian state's formations of heritage, passionately rejected. Interestingly though, the very same people who have difficulties in appropriating the state version, now tend to easily embrace new, market driven cultural forms that symbolize Africanness. The question of how these modes of heritage making differ, and to some extent converge, is central to this article.

Second, as a construction subject to dynamic processes of (re)inventing culture within particular social formations, heritage is bound to particular forms of mediation. Heritage and media are therefore not to be understood as separate realms merging in the process of media representation (that is: heritage as given, existing as a premediated essence), but heritage is intrinsically mediated. It does not exist outside particular media forms (museums, monuments, written and illustrated canons, TV programmes, websites et cetera); rather these forms produce and frame certain items as heritage. Analyzing modes of reframing heritage in contemporary Ghana, we argue that what is new is not the coming together of heritage and media per se, but the mobilization and expression of heritage in a particular, largely commercialized media field.

Thus, this article explores the plurality and dynamics of cultural heritage in Ghana by looking at key players in the historically constituted heritage arena and the contestations between them. Focusing on the intersecting domains of the state, religion, and entertainment media, it discerns several tendencies with regard to the framing of cultural pasts: a (partial) shift of the state project of heritage formation from national identity politics to transnational economics of roots tourism; a contestation of heritagization by Pentecostal churches that view tradition and heritage as demonic and dangerous; a revaluation of tradition and heritage as design, put on display in local television and video making. Discussing the examples of the recent 'epic' genre of video films and the local commercial television station TV Africa, a station geared towards the promotion of African heritage, this article shows how recent, marketdriven trends towards a more stylish representation of African heritage depart from earlier state initiatives. Those rejecting the latter quite easily embrace the former 
which are characterized by an explicit focus on design and visual style. Spotlighting intriguing links between heritage and visual aesthetics, we argue that issues of style, design, and commerce require more attention in research on the dynamics of heritage making.

\section{The Ghanaian state: Sankofaism}

In post-colonial Ghana, the concept of heritage has historically been cast in the nationalist framework of 'Sankofaism.' Since Independence (in 1957) Ghanaian governments faced the problem of how to create a unified nation out of many different ethnic and religious groups. To solve this problem the state developed a cultural policy that sought to revive and propagate Ghana's diverse cultural heritage, thus recognizing cultural diversity within a national identity that transcends ethnic and religious boundaries.

This nationalizing project took shape around the Akan symbol of Sankofa, a bird looking back and walking forward (fig.1). Originally, the symbol, first only existing in a more abstract heart-shaped version, expressed the Twi proverb 'worefi na wosankofa a, yenkyi' - it is not a taboo to go back and fetch what you have forgotten, meaning 'one can always undo past mistakes.' Now, in the framework of post-colonial identity politics, Sankofa, translated as 'go back and take it,' came to express the need for cultural heritage in moving ahead as a people. The fact that the bird's feet are pointed forward is often emphasised to show that not a complete return to the past is aimed at, but a selective picking from long-standing traditions and past experience and wisdom while taking new steps of cultural self-definition to build the future.

Figure 1



Sankofa symbol on the fence wall of the TV Africa studios, Accra. (C) Marleen de Witte. 
Closely connected to Kwame Nkrumah's ideology of African personality, Sankofa meant modelling a recovery of the 'authentic' African selfhood lost in alienation by returning, in a mode of self-retrieval, to the cultural heritage that colonialism taught Africans to forget or reject. This was seen as a precondition for the development of the country. It also meant seizing new institutions of self-definition, such as the modern nation-state, as a path to cultural authenticity. From the 1960s onwards this state-centrist model determined cultural policy for a long time, until the 1990s. It still informs the work of the National Commission on Culture, whose policies, however, have become subject to public contestations. Under the ideology that came to be known as Sankofaism, state cultural policies, especially during the military regime of J. J. Rawlings (1981-1992) tried to facilitate the formation of a national cultural heritage, and restore people's identification with and pride in it, by supporting the chieftaincy system and the celebration of traditional cultural festivals, preserving heritage sites, adopting national cultural symbols, funding research on Ghanaian traditions in African Studies departments of national universities, teaching about the cultures and traditions of Ghana's various ethnic groups in school curricula and books, and stimulating media production on Ghana's 'rich and colourful heritage.'

Obviously the representation of certain cultural forms as heritage implied selection, polishing, and framing. Within the framework of Sankofaism, the valuable aspects of the diverse cultures of Ghana were to be identified, recovered, and re-presented in the frame of a national heritage style. In practice, this entailed a strong preponderance of Akan culture. In addition to the adoption of Akan adinkra symbols, including Sankofa, as symbols of the Ghanaian nation, Akan chieftaincy provided a particularly rich aesthetic resource for Kwame Nkrumah. He adopted royal insignia that symbolized state power in Akan chieftaincy - such as stools, swords, linguist staffs (as well as the office of the linguist or okyeame), and kente cloth - to Africanize and legitimize the authority of the modern nation-state. The emphasis was on chieftaincy's aesthetic power, which in the framework of the modern nation-state came to be disconnected from its traditional connection to political and spiritual power. The Ghanaian state mobilized the splendor and spectacle of the chieftaincy tradition in representations of the nation so as to persuade the new nation and the outside world of Ghana's cultural wealth and uniqueness, but severely curtailed the chiefs' influence in the new political order (Schramm 2004).

Sankofaism was a post-colonial project in a quite direct sense of the term, explicitly aimed at undoing the alienation of colonialism and restoring the African self. But while the post-colonial discourse strongly emphasised a rupture with the colonial legacy, the search for African heritage betrays more continuity with the colonial period than is usually assumed. The British administration, in promoting Indirect Rule, hinged on the idea that progress in the Gold Coast could only be realised if it built on African

The Ghana Television (GTV) broadcast 'Cultural Heritage,' for example, featured an overtly educational talk show hosting cultural specialists who elaborated on specific topics like 'traditional religion,' 'cultural festivals,' or 'libation.' The program ran from the 1980s to the late 1990s, when GTV considered it 'no longer relevant.' 'By the Fireside' brought Ananse stories in a rural village scene. Such programming was part of a pedagogical project designed to educate citizens on the value of cultural heritage and prevent them from drifting away from 'their own' culture. 
traditions. To achieve this, people had to retain pride in their 'traditional past' and the most effective way for the colonial regime to do this, was through its schools (Coe 2006: $57 \mathrm{ff}$.). Teaching tradition in colonial schools particularly focussed on drama, dance, and drumming, but also included art. ${ }^{5}$ In short, the mobilization of heritage in the framework of Sankofaism as a building block for progress already started during the colonial regime and had been stimulated by colonial institutions themselves. After Independence, postcolonial governments and elites appropriated colonial discourses of culture (as a bounded essence, tied to a particular people - Lenz 2006; Meyer 2002) while at the same time advancing a particular representation of the colonial past as destructive of African culture. Sankofaism thrived on a paradoxical political strategy that affirmed the African self so as to shake off British domination, yet, in so doing, recurred to colonial constructions of culture and tradition (Woets 2011: 91).

In the making of a national cultural heritage, local cultural traditions were further transformed, objectified and nationalized. As noted, up to the present, state institutions such as the National Commission on Culture work within the framework of Sankofaism. The Commission promotes local cultural festivals in various regions, thereby involving chiefs and related traditional representatives as 'custodians of culture.' It also assigns an important role to the arts, especially theatre, dance, and film in retrieving and mediating past cultural forms as heritage. This process, however, also subjected Sankofaism to much negotiation and contestation and generated fierce and occasionally violent public controversies over issues of culture and tradition. Contestation has come from a number of angles. Not only do ethnic groups complain about the 'Akanisation' of Ghana, pointing out that those items presented as symbols of the nation are predominantly Akan. ${ }^{6}$ Also, a great deal of Christians, in particular those close to Pentecostal-Charismatic churches, reject traditional culture on spiritual grounds, while, conversely, custodians of tradition, including chiefs and neo-traditionalist religious groups, object to the reduction of traditional culture and religion to 'mere' heritage. If the former claim that the celebration of heritage is dangerous because it revives traditional spirits that are perceived as demonic, the latter fear that lived traditional culture is immobilized as powerless folklore.

While the project of heritage formation was thus not uncontested from the beginning, the turn to democratic rule and neo-liberal policy in the nineties, and the transformation of the state-controlled public sphere into a liberalised and commercialised arena, has intensified pressure on Sankofaism as a nationalist project. A plurality of voices could now access the media to challenge state cultural politics and articulate alternative formations of identity and belonging (De Witte 2005, 2008; Meyer 2004). At the same time the iconography of Sankofa appeared attractive for a wide range of actors and groups, who appropriated and redesigned it for various

5 Rhoda Woets (2011) has described how British art teachers at Achimota school strongly stimulated an engagement with African heritage, motives and aesthetics and a revaluation of 'traditional arts and crafts' among their students, who were often much more interested in European art traditions than in local art traditions and culture.

6 The strong focus on Akan culture is symptomatic of a broader politics of representing Northern Ghana as marginal to the core of the nation. 
ideological, cultural, religious, or commercial purposes. Meanwhile, the state shifted focus to promoting Sankofa in the context of black heritage tourism and diasporic investment in Ghana, thus moving, at least partially, from national identity politics to transnational economics (Bruner 2004; Hasty 2002). Answering the needs and desires of African-American and Caribbean roots tourists, many of whom have eagerly adopted the symbol of Sankofa, the state offers them a heritage to reclaim and emotionally engage with in the form of the old slave castles in Cape Coast and Elmina and other slave sites, and lavish displays of 'culture' at festivals like the biennial Panafest and Emancipation Day (Holsey 2009; Schramm 2010). ${ }^{7}$ At the same time, within Ghana itself this particular promotion of Sankofa in relation to roots tourism by and large has little resonance. ${ }^{8}$

Importantly, the celebration of heritage under the banner of Sankofaism has a performative dimension. Making the past available through particular symbolic markers and performances, 'heritage' necessarily is to some extent 'invented' and 'staged.' A tension exists between Sankofaism as an ideology that makes claims about retrieving the past, on the one hand, and its stylized performance, on the other. This tension indicates an instability inherent in the notion of 'heritage' as it is being used in the Ghanaian setting. 'Heritage' may be understood as an expression of a true national culture backed by spiritual powers and rooted in the past, or as some kind of folklore. While some people take heritage to be a genuine - either positive or dangerous substance, others regard it as a ('mere') display. The contestations of Sankofaism and negotiations of cultural heritage analysed in this article evolve around this tension.

\section{Pentecostalism: contesting cultural heritage}

As noted, one of the major challenges to the state's promotion of cultural heritage came and still comes from Pentecostal churches in Ghana. ${ }^{9}$ Since the 1990s, the popularity of Pentecostalism and its influence on public and popular culture grew rapidly, as these churches massively made use of the opportunities for public presence offered by the liberalisation and commercialisation of the media (AsamoahGyadu 2005a; De Witte 2003, 2011; Gifford 2004; Meyer 2004). Pentecostalism's colonization of the public sphere, together with the state's increasing acknowledgement

7 An excellent example of an African-American adaptation of Sankofa symbolism to the longing for an engagement with African roots is Haile Gerima's feature film Sankofa (1993) that tells the story of an African American model travelling to the slave forts in Ghana, where she gets possessed by the spirits of enslaved Africans lingering on in the dungeons of Cape Coast castle.

8 Holsey shows that next to the predominant deployment of a public silence about slavery on the part of the inhabitants of Cape Coast and Elmina, educated youth start to develop new ways of engaging with slavery. They stress a shared black identity of African and African-Americans that contests global inequalities (2008: 221-232).

9 Pentecostalism is a highly diverse movement within Protestantism that places special emphasis on a direct and personal experience of the Holy Spirit and on deliverance from evil spirits. Although the origins of classical Pentecostal churches in Ghana can be traced back to 1917, African-founded Pentecostal-charismatic churches have become very popular since the 1990s. They proclaim a message of success and prosperity, attracting not only the young upwardly mobile, but also successful executives, businessmen and politicians. 
of Pentecostalism as wielding a major influence on a great deal of the electorate (certainly in the South), has seriously weakened the appeal of Sankofaism as a national identity project. With democratization, a great deal of elected politicians also present themselves as born-again Pentecostal believers.

In the Pentecostal worldview African traditional religion is perceived as the extremely dangerous domain of evil and demonic powers that operate under the auspices of the Devil (Meyer 1999a). Building on the ideas of 19th century missions, the current Pentecostal contestation of heritage mobilizes an alternative imagination of the past that represents indigenous culture and religion as 'heathendom.' Pentecostals do so in marked contrast to the historical mission churches, that embrace certain elements of Sankofaism and deploy a more positive attitude towards traditional culture. Pentecostal moral practices of 'making a complete break with the past' - perceived as spiritually loaded - directly oppose Sankofa ideology of retrieving from and indexing that past. Highly suspicious of the demonic power that state cultural policies are found to be prone to conjure with their positive attitude towards local cultural and religious traditions, Pentecostal churches promote alternative identifications and forms of belonging grounded in being born-again. Championing progress and development, they aim at Christianising, and by the same token exorcizing, the nation. ${ }^{10}$

The Pentecostal crusade against cultural heritage has yielded a number of controversies and clashes, such as that over the pouring of libation at public functions (Van den Bersselaar 2007: 237 ff.; Van Dijk 2001). Conceived as the traditional form of prayer, the state incorporated the practice of libation together with the Christian prayer and the Muslim prayer at state functions to represent the 'three major religious traditions' in Ghana and express the multi-religious character of the nation (Sarpong 1996). For Pentecostals, and a great deal of Christians at large, however, libation is utterly problematic as it is held to invoke the dangerous presence of evil spirits. Discussions about the cultural-religious practice of pouring libation to the ancestors have a long history in Ghana, but resurfaced again in 2002, when a Pentecostal Government Minister publicly called for the abolishment of libation pouring at state functions. After the Minister's call, a hot debate followed, in which Pentecostal statements about 'invoking evil spirits in the nation' and 'idolatry changing the country's destiny' clashed with arguments about 'Africanness,' 'freedom of worship,' and 'national cultural heritage.'

Another example of clashes about heritage is the destruction in 2001 of the public statue of the legendary Asante priest Komfo Anokye (fig. 2), who is famous for allegedly having drawn down the Golden Stool from the heavens to affirm the foundation of the Asante kingdom in 1695. On 30 July 2001 a Pentecostal evangelist demolished the statue in Kumasi with a hammer while wielding a Bible. He claimed that God had appeared to him in a vision and told him to destroy this 'idol' (McCaskie 2008).

10 The increasing encroachment of Pentecostalism upon Ghana's public and political life (AsamoahGyadu 2005b) has entered a new phase with the election in 2008 of current president John Atta Mills, a born-again Christian, who expressed the wish to turn Ghana into a 'prayer camp.' 
Figure 2

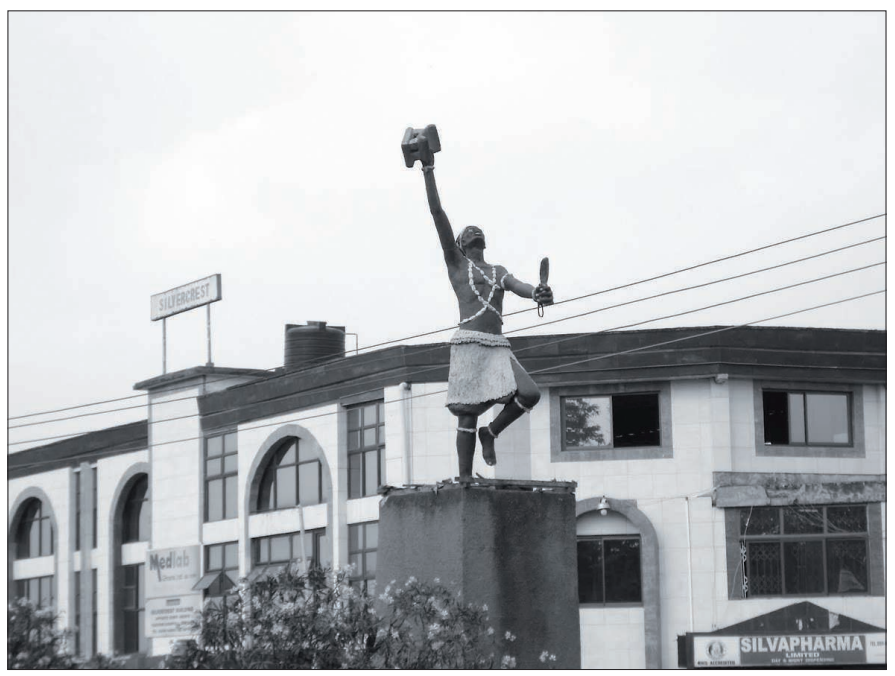

Statue of Okomfo Anokye in Kumasi before it was demolished. (C) Photographer unknown.

What Pentecostals contest in these examples is not only the status of traditional religion as equal to Christianity (in the first case) or as part of the nation's cultural heritage (in the second), but also the invocation of demonic spirits into the public domain. Such contestations are part of a broader Pentecostal emphasis on the potential presence of demonic spirits in objects, images, sounds, and performances that are legitimized and nationalized though the framework of cultural heritage. Whereas Sankofaism seeks to recover the positive values found in African traditions so as to foster national development, Pentecostalism points at the danger of spiritual forces inherent in things associated with African tradition and cultural heritage and fights against their destructive implications. Those in favor of cultural heritage, framed along the lines of Sankofaism, find themselves in a defensive position vis-à-vis the Pentecostal assaults, always 'talking back' in terms that have been already set and that hark back to colonial discourses on tradition and culture in the framework of Indirect rule (De Witte 2004, 2008; Meyer 2005). The point here is that, from the Pentecostal perspective, 'heritage' as deployed by Sankafoism is not taken as a harmless performance, but as a dangerous substance that renders present the past. Of course, what is featured as the past in this perspective is shaped through the Pentecostal imagination. In other words, Pentecostals, too, produce and stage the past, albeit as a bad thing.

The public dominance of Pentecostal views nurtures a widespread fear of and animosity towards traditional religion and its places and practitioners. At the same time, however, people are also fascinated by this 'dangerous evil.' Popular media feed (and feed on) such popular fears and fascination with sensational stories and images of 'juju priests' and their 'occult' practices, commercialised via video movies, tabloids, posters, and calendars for sale on the streets (De Witte 2005; Meyer 2010). 
Exploiting the mode of the spectacular to the fullest, tabloid front pages scream about the horror in traditional shrines, calendars depict the skulls, coffins and fearsome icons that shrine priests allegedly work with, and video-movies spectacularly show the destructive consequences of engaging in shrine rituals. Though less wellknown than the Nollywood phenomenon (Haynes 2000; Austen and Saul 2010), the Ghanaian video-film industry operates in roughly the same manner, and has long been characterized by a remarkable closeness to audiences' preferences for Christian themes, offering spectacular plots and scenes on the basis of the dualism of God and the devil that underpins Pentecostal life worlds (Meyer 1999b). A great deal of movies have echoed people's negative stance towards heritage, often cast as the realm of the 'powers of darkness' from which people are to be delivered. Mirroring the Pentecostal world-view, this stance contrasts remarkably with so-called African Cinema, and in particular Return to the Source films (Diawara 1992: 142), that seek to retrieve and revive an African heritage from which people had been alienated through colonization and modernization.

From the outset, when the video-film industry arose in the mid-1980s to make up for the incapacity of the virtually defunct state film industry to produce 'Ghanaian films,' there has been a continuous struggle over video-movies. While intellectuals and those involved in the state film establishment seek to induce a more positive attitude towards heritage, video-filmmakers stress that they need to please the audiences in order to sustain their business. For both sides, mobilizing the past involves processes of styling and display, but they do so with different aims. Typically, following Pentecostal views, in this kind of video-movies heritage is not approached as something to be captured and displayed into film images so as to show good values from the pre-colonial past, but as thriving on invisible powers that are potentially dangerous and very much present. Ironically, then, many video-filmmakers - or at least their imagined audiences - tend to take heritage quite seriously as a living matter of the present which they seek to rebuke and lay at rest as 'the past,' whilst from the perspective of Sankofaism it is a matter of the past that needs to be saved from being forgotten. Those opposing heritage from a Pentecostal perspective tend to take it to be more powerful than those who celebrate it as a cultural performance (Coe 2005).

\section{Designing African tradition}

However, as noted in the Introduction, as elsewhere in Africa since around 2000 there is a trend towards a broader revaluation and new aesthetics of African tradition among young urbanites (Becker 2008; Comaroff and Comaroff 2009). Operating as a kind of seismographic devices to discern current moods and imaginations, urban popular culture and media crystallize - and by the same token reinforce - this trend. In what follows we briefly discuss the rise of a new genre of so-called epic movies and the emergence of the private television station TV Africa that is devoted to projecting 'African values.'

\section{Epic video films}

When Meyer started her research on video-movies in the early 1990s, she noted a strong contrast between the movie Heritage Africa (1989) by the famous Ghanaian 
private film maker Kwaw Ansah - the founder and owner of TV Africa - and the videomovies made by private producers (1999b). Epitomizing the spirit of Sankofaism, Heritage Africa is about a black colonial official's painful alienation from his past and culture, and his eventual, dramatic reunification with his heritage - symbolized by a sacred heirloom from his family that he had initially given away as an item of tribal art to his colonial master - at the moment of death. The movie advocates a careful and selective retrieval of the past. As Meyer found out through her research, the film was cherished among members of the educated elite that supported the Sankofaist project, but less popular among ordinary film audiences who were not keen to watch movies set in colonial times and preferred melodrama of some sort. ${ }^{11}$

While in Ansah's movie the heirloom that had been lost by the black official through colonial brainwashing could - and should - be retrieved so as to heal the wounds of colonial alienation, in video-films such items were featured as a major source of trouble and anxiety - indeed: a curse more than just heritage - that had to be gotten rid of, thereby echoing the Pentecostal stance. Many movies attribute mishap befalling people to some secret indigenous powers, represented through heritage items. Shrines of traditional priests are often adorned with figurines and adinkra symbols that would be coded as cherished heritage items in Sankofaist discourse. And even masks, though not featuring in local traditions, are prominent paraphernalia. Right from the outset, video-filmmakers were constantly criticized for their negative representations of heritage by intellectuals and the state film establishment (Jorgensen 2001). They were admonished to make movies that were geared to 'preserving good cultural values, and presenting a good heritage,' as the chairman of the National Commission of Culture, the philosopher and anthropologist professor George Hagan, put it in a speech for filmmakers at the occasion of the first anniversary of GAFTA (Ghana Academy of Film and Television Arts) on 31 October 2002 (Meyer 2010).

At the time of Hagan's speech, the new genre of so-called 'epic' films - or, as they are usually called by marketers and audiences, 'history' or 'old times' films - started to emerge. Inspired by similar Nigerian productions, this new genre was introduced to Ghana by Samuel Nyamekye, director of Miracle Films. This is a quite fascinating genre that pictures beautiful, green villages situated in times immemorial, 'way before people knew Mohammed and Jesus.' Since in the timeframe of the 'epic,' Christianity is not yet an option, Christian viewers can be perfectly happy watching it. Meyer was intrigued to find out that, far from seeking to offer truthful representations of the past, filmmakers use this genre to, as one Nigerian set designer put it, 'create unexisting traditions.' There is an emergent visual language of the 'epic' that makes chiefs, priests, and commoners easily distinguishable by their dress, behavior, and symbols. This visual language is situated beyond existing ethnic groups and cultural settings, but can be described as 'pan-African' in a broad, sweeping sense. Instead of relating to the past in an attempt of retrieval, the epic involves 'a temporality that is very much of the

11 Many people interviewed by her expressed that the colonial setting did not appeal to them, they found the movie old-fashioned, or as they would put it, "colo." They much preferred Ansah's previous movie Love Brewed in an African Pot (1980), which is about a difficult love relation between an ordinary fisherman and an educated girl whose father, who is shown to be alienated from his own culture, strongly opposes their marriage. 
present,' adapting tradition to the global age (Comaroff and Comaroff 2009: 114). As cultural entrepreneurs, filmmakers are very much aware that they imagine - indeed: image - tradition through a distinct visual language. Meyer's friend, the filmmaker Akwetey-Kanyi stressed that, in his epic film Sacred Beads (Aak-kan Films, 2009) he had to create images of tradition and heritage (fig. 3). Though he was quite familiar with local religious practices, in his view it would not be sufficient to simply represent these matters realistically in a film. In order to make the movie pleasurable for viewers, it was important to choose beautiful bright colors, even though in the past people wore plain light cotton cloth. And though traditionally tremendous power is found to be located in a simple pot, film shrines offer more spectacular food for the eyes of the spectators. The colorful visualization of tradition and heritage in the 'epic' suggests a new emphasis on visual markers aimed at affording viewers a pleasurable experience. Far from referring to a set of cherished values rooted in the past, tradition here rather is invoked in the framework of a mode of signification designed to speak to viewers' imaginations (as is also argued by McCall (2007) with regard to 'Nollywood's invention of Africa'). In this sense, epic films offer an alternative to the moralizing discursive framework of Christianity versus traditional religion, which prompts people to take sides and identify themselves with one option, but, at the same time, do not disrupt that framework because the 'epic' is set in a pre-Christian time. The main appeal of the 'epic' lies in its lavish display of markers of African culture that are to please the eyes of the beholders.

Figure 3

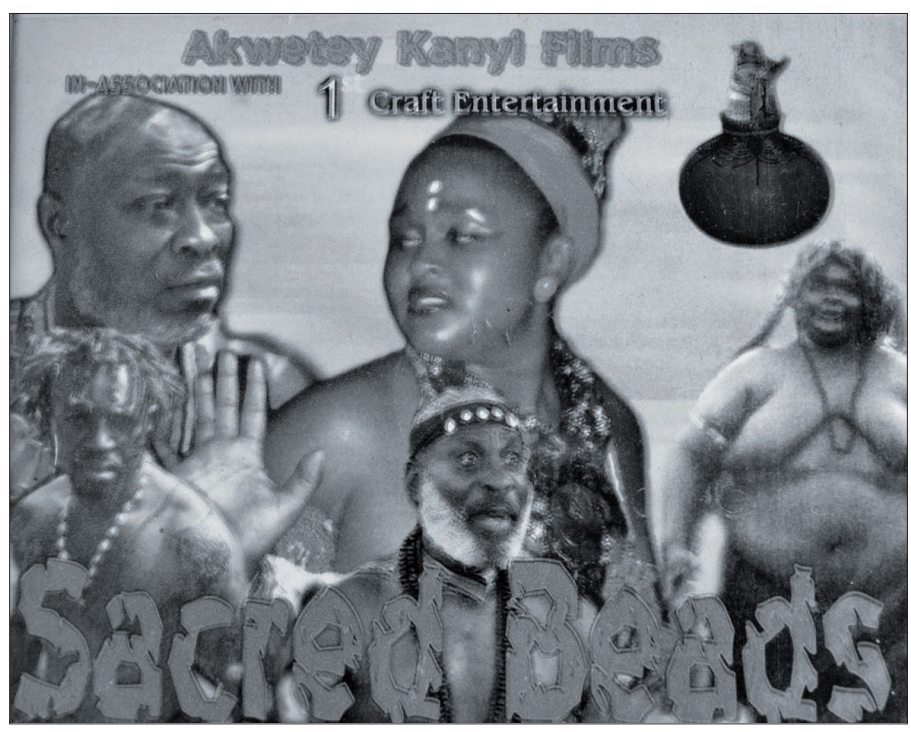

VCD cover, Sacred Beads. (C) Birgit Meyer.

Interestingly, however, the genre of the 'epic' has not been very successful. Those in favor of a positive representation of heritage disliked the lack of historical accuracy 
that went along with the creation of 'new traditions.' This was clearly not in line with the Sankofaist project of turning back so as to appropriate certain good things from the past because of their high moral value. The main emphasis was on a lavish display of nice symbols of Africanness that could be embraced by black people throughout the world (and in fact, the movies themselves travel wide throughout the African diaspora) - and that, as set designers explained, were inspired not by actual research but by coffee table books on African culture. Promoting these movies with slogans like 'Tradition and Colour at its Best,' epic movies sought to display nice pictures for the eye, but had no substantial message about the value of tradition as a moral order or even showed this order to be backward and problematic.

Though the movies had some popularity, on the whole audiences were and still are more keen to get movies situated in the present, displaying fancy settings in Ghana's capital Accra, including stylish hotels and restaurants, exuberant mansions, and posh cars. It is in such settings that signs of Africanness are being featured, especially regarding fashion and interior design. A fine example for this trend is Princess Tyra (Venus Films, 2007), a movie about a royal family situated in Accra's upper class (fig. 4). Eager to 'introduce new styles of royalty,' as the producer Abdul Salam put it to Meyer, the movie combines markers of African chieftaincy (clothing, traditional jewelry) with invented rituals, such as the throwing of flowers in from of the princess' feet, all set in a fancy urban setting of conspicuous consumption. This introduction of 'new styles of royalty' resonates with a broader process of re-coding heritage as stylish design, as the emergence of glossies, African fashion-shows and similar features shows.

Figure 4

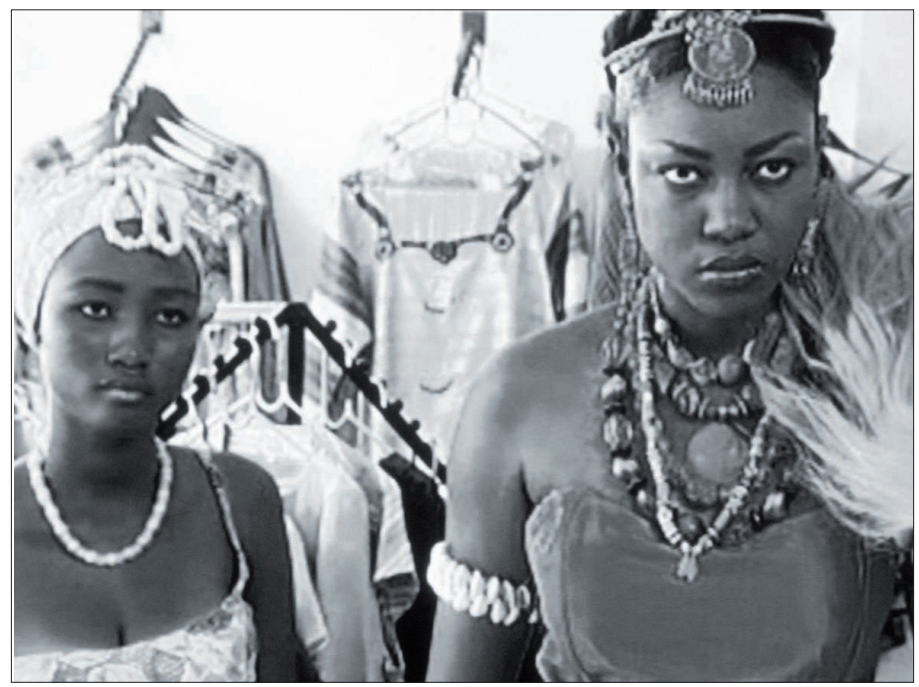

Video still from Princess Tyra.

(C) Birgit Meyer. 


\section{TV Africa}

A more successful initiative of restyling African tradition in commercial media is the private television station TV Africa. Founded by filmmaker Kwaw Ansah as a free on air station in 1995, when Ghana's airwaves were deregulated and private broadcasting was made possible, it started operating from its studios in Accra in 2003, with the slogans 'TV Africa: Truly African, Proudly Ghanaian' and 'projecting African values.' The station's mission to 'uplift and enhance the soul and image of the African, both on the continent and in the diaspora', strongly echoes the ideology of Sankofaism. As noted above, Kwaw Ansah indeed comes from the Sankofaist intellectual tradition that seeks to decolonize the African mind by shedding of European perversion and retrieving African heritage. With his TV station, Ansah still aims at 'restoring the confidence of the African' by 'turning round to see what has gone wrong and use the goodness in what our ancestors left us.' And indeed, the symbol of the Sankofa bird is all around at the TV Africa premises: as an art work decorating the gate, in the wood carvings on door panels and furniture, or on wall hangings in stairways and offices. The primary objective of the station is to 'uplift the image of the African in a world media environment that is generally hostile to the African image.'

What makes Ansah's television project different from his earlier filmmaking practice is the commercial nature of the TV station, and its explicit branding and marketing strategy. The station's glossy marketing brochure states:

This objective [of uplifting the image of the African] has also been achieved by a differentiation strategy, which allows the station to target a particular niche of the market. The brand has been made to look indigenous. This makes those who have an African lifestyle and taste for African products/services the target audience.

In an interview, Kwaw Ansah told De Witte that a few years ago it would have been impossible to even think of a commercial TV station that puts African heritage at the forefront, such was the general craving for things Western and the dislike of things African. Today, there appears to be a growing market for things African, especially so among young urban middle classes. While the ideological backbone of TV Africa shows a continuity with earlier Sankofaism, Kwaw Ansah's conscious choice to assemble a group of young media makers to repackage African heritage in formats that appeal to this new market also points to the new directions he is taking.

The 'mantra' of 'projecting African values' finds expression in a wide variety of home-produced programmes that are 'geared around African heritage,' as Nana Banour of the marketing department phrased it. A very successful programme in 2010 was the 'Omanye Aba' talent show, that featured a competition between cultural troupes from various 'indigenous' Ga communities in the Greater Accra Region that performed aspects of their community's cultural heritage - e.g. town history, festivals, royal funeral rites, marriage rites, traditional dance, et cetera - in a weekly live show from the TV Africa studio (fig. 5). Other programs explicitly focusing on African heritage in their content include 'Amazing Child,' another talent show where children from various parts of Ghana 'exhibit their impeccable knowledge on culture and heritage in grand style,' 'Knowing Africa,' a game show with high school kids 
answering questions about African history and culture, 'African Kitchen,' that 'seeks to re-discover the healthy foods that kept our forbears healthy,' and the 'African Proverb' that follows each news broadcast and is selected from all over the continent. As the title 'Knowing Africa' makes clear, the educational focus that characterized GTV's earlier 'Cultural Heritage' talk show has not disappeared. What is different, however, is its packaging in popular formats that emphasize pleasure and excitement, feature competition, allow for audience participation (e.g. by SMS voting in talent shows), and contain strong stylistic references to global commercial media culture. For programs that are less heritage-oriented in content, including the English language news and current affairs talks shows, the 'African heritage' is to be found first of all in the visual styles.

Figure 5

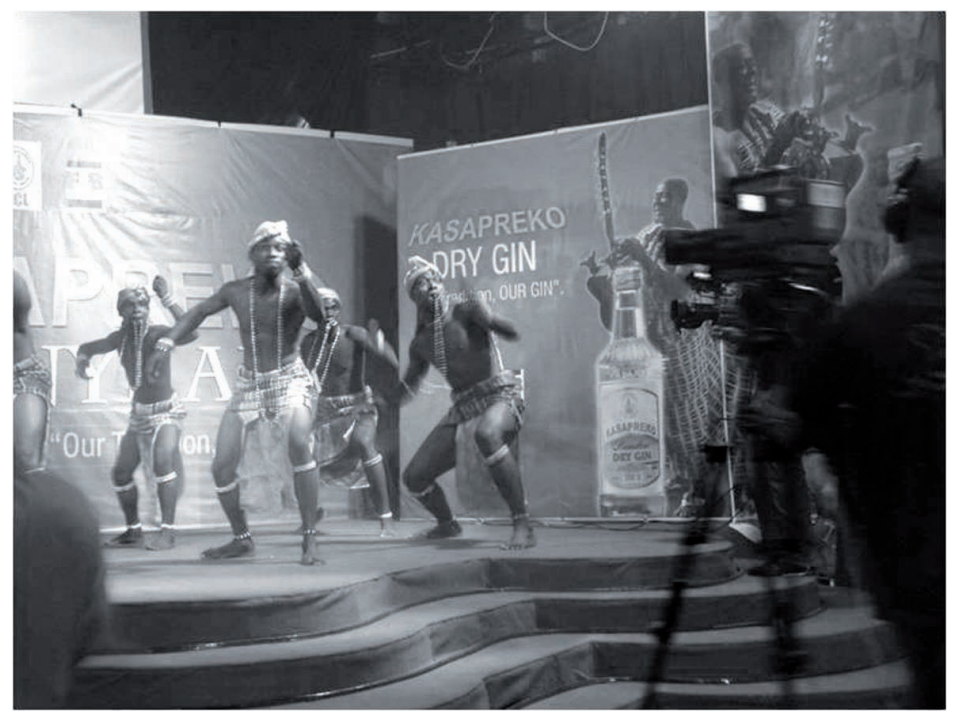

Omanye Aba reality show, TV Africa.

(C) Marleen de Witte.

At TV Africa, De Witte talked with set designers Akpezua, Frank AsempahKofitse, and Daniel Ofosu about this 'African style' and the 'indigenous looks' of the sets they make. 'Colours, symbols, shapes, objects, you blend anything African that is appealing enough. We adopt it and we project it... you try and put them together to get something interesting that will represent our values.' Like in the case of the epic films, TV Africa's set designers turn to the ancestral past as a source of inspiration and understand 'African' as free of Western influences. Pointing at a black earthenware pot on display at one of the sets, Akpezua explained that 'In those days people used it to cook, they were using a fire and that will make things black. And those days there was no "silver" [aluminium cooking wear common today]. Now nobody uses the pot for cooking any longer, not even in villages.' Today the earthenware cooking pot has become a decorative icon of Africanness. 'If we are building a set and we have 
a coffee table, I will put the pot on it so that it will make the set look African.' Other elements used to give the sets the required African look include objects like sculptures, royal stools, bowls; natural materials like calabash, rattan, and wood (fig. 6); different types of cloth, textile art with abstract patterns or adinkra symbols, and predominantly warm colors, with gold being TV Africa's brand color that appears (as gold, yellow or light orange) in all sets, public relations materials and screen graphics. Looking at 'what our people where doing in the past' as a source of pleasure refers the designers not only to Ghanaian traditions, but to the whole of the African continent. Kwaw Ansah, being a visual designer himself, as well as a frequent traveller and an ardent collector of African art, has brought heritage objects such as traditional masks and textiles from various African countries. Two Fang masks, for instance, adorn the Viewer's Choice set and Malian bogolan cloth is used as wall hanging or furniture upholstery. There is natural heritage too: zebra and giraffe motives; acacia, baobab and coconut trees; an image of a Serengeti sunset - all globalised and clichéd icons of African nature. Combined with stylish wooden or wrought iron furniture and modern studio equipment, all these elements blend into an iconic 'African style' that is clearly recognizable as TV Africa's. 'When you see it you know that it is TV Africa. You immediately recognize the style,' Daniel said. The crux of TV Africa's design is to establish its brand distinction amidst a variety of stylistic choices that are available to consumers of media products distributed through the market and to bind audiences to this style as consumers.

Figure 6

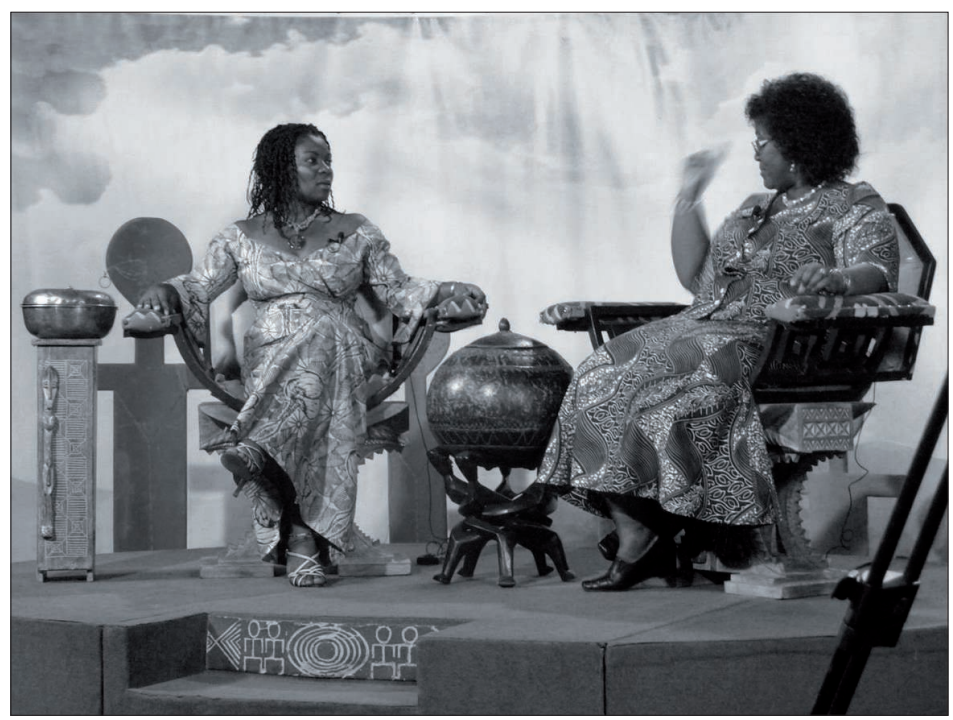

Sbaa Mbo talk show, TV Africa.

(C) Marleen de Witte 
The station's dress policy also contributes much to this brand recognizability. All presenters must wear African dress and beads when they appear on TV. TV Africa has a well-stocked dress room with a large variety of kaba-and-slit styles, ${ }^{12}$ boubous, head ties, men's shirts, tunics, and togas, all made of colourful African wax print fabrics ${ }^{13}$ or handcrafted adinkra or kente cloth and updated regularly. There is a large collection of beads and other African style jewellery to match with the dresses. News readers must at least wear an African top and hide their jeans under the table. Floor managers and production assistants who may appear on screen during live shows with in-house audiences are required to wear the black TV Africa T-shirt with gold-printed logo and slogan. There is no explicit dress code for studio guests, but most of them, knowing that they are coming on TV Africa will 'come in their finest African wear.'

Most employees De Witte spoke to at TV Africa recognized that compared to a decade ago African styles of dress are becoming more fashionable among young people in the city, including themselves, who are looking for new ways to express an 'African' identity. Some saw it an almost natural progress towards modernity: 'You see, how the world is moving... we have something called 'modern Ghana.' That is how it is: we are moving forward, so people think: once I am African I have to use African wear.' Some noted how African style spreads like fashion: 'You will see it and you will be happy about it. Then you too, you will go and buy some, and then you too. And even your friend outside: "ah, where did you get this thing from? African made, it is very nice." And he too he will be interested to get it. That is how it is.' Others recognized the impact of former president Kufuor's (2000-2008) initiative of introducing 'Friday African wear' among civil servant and private sector workers, obliging them to wear African dress every Friday (adopting the global 'Casual Friday' trend) so as to stimulate national textile production and dress making. TV Africa not only reflects this new trend, but also sees it as its mission to further promote African styles.

Promoting African style is not just a matter of 'bringing out the beauty of African things,' as TV Africa's beads designer Lydia Amankwa put it. One also needs to confront a still widespread distrust towards items such as beads, rooted a belief in the presence of spirits in ancestral things - a belief that is, as noted above, reinforced by the dominance of Pentecostalism. Explaining why her beads business faced difficulties in the beginning, Lydia said:

12 'Kaba and slit' is the most common Ghanaian style of dress for women. It consists of a skirt, a blouse, and sometimes an additional wrap-around cloth that can also be worn as a turban. They are personally tailored, mostly of African wax or print cloth, and come in a wide variety of designs (see Gott 2010).

13 Widely recognized as typically 'African,' wax print cloth is the outcome of a thoroughly globalized history of trade and creative exchange connecting Europe, Africa and the Far East. Its origins trace back to early-nineteenth century Dutch and English textile companies that started to produce factory-made versions of Javanese batiks for West and Central African markets (Gott 2010: 15-16). Today, African wax print is still produced in Europe, but also in West Africa, and, since recently, China. 
For some years, because of the ways our grandparents were using beads for traditional things, for ritual and fetish ${ }^{14}$ and other things, the younger ones have some funny view of using the local bead. Most of them think that some of the beads contain spirits. You know, those days, when an old woman gave you a gift like this, it's a spirit, it's like giving you a witchcraft or something. Many still have that mentality.

Such ambivalence or even fear also concerns other ritual items such as clay pots or cowry shells. Appropriating them as cultural elements symbolizing African heritage thus requires disconnecting them from the power of spirits and re-styling them as fashion, downplaying 'cultural essence' and highlighting beauty and design. For the young media professionals working at TV Africa, embracing this style can go together with a Pentecostal identity very well. Many of them are Pentecostal Christians, as they eagerly publicize in their Facebook posts, but they have no problem wearing local wrist beads or even welcoming a traditional priestess ('you know, those who worship the idols,' one of them explained to De Witte) on the jury board of the 'Omanye Aba' show. Apparently, tradition (including traditional religion) sufficiently designed in a media format is tradition 'made safe.'

At TV Africa, Africanness thus becomes a matter of brand distinction, of lifestyle and taste. Although TV Africa's stylistic emphasis on heritage as its brand mark works to create a niche in the national media market, distinguishing it from other Ghanaian TV stations, it is clearly part of a broader, transnational revitalization of African culture and tradition as a style that connects young urban middle classes across Africa and the African diaspora (Becker 2011: 539-39; Comaroff and Comaroff 2009; Ferguson 1999; Nuttal 2004; Shipley 2009; Thalén 2011). Part of a global 'rebirth of Afrocool,' as the glossy Canoe magazine founded by Kwaw Ansah's son Kweku Nkwaye Ansah puts it, this new emphasis on the beauty and power of Africa is a far cry from the political moralism of earlier Sankofaism, and instead dons African authenticity and pride in style and fashion. In the current neo-liberal era, new mediatized forms of heritage address audiences not as national citizens who must not forget their heritage lest they become alienated, but seduce them to buy into attractive identities designed to fit globalized consumer lifestyles that make them feel good and on top of the world as Africans. This is much in line with the argument made by John and Jean Comaroff (2009: 18, 28) that commodified 'culture' circulates easily through the circuits of the global market and at the same time is easily embodied through affective attachment .

And yet, the commercial exploitation of African heritage by a station like TV Africa does pose tensions that derive from the coexistence of the various takes on heritage that we have discussed. A criticism levelled at TV Africa by more radical traditionalists is that this is shallow entertainment, devoid of the 'real power' of tradition and corrupted by Western-styled commercial formats and the love for money. Also, Kwah Ansah himself is highly critical of Pentecostal churches and their negative attitude towards traditional African culture. Yet, in order to survive as a commercial

14 Originally coined by the Portugese (feitico) as a derogatory term to refer to the religious statues they found in shrines, the term 'fetish' is now commonly used by Ghanaians to refer to traditional religious practices, priests, and ritual objects, both negatively and neutrally. 
station, TV Africa cannot do without Pentecostal churches buying airtime and thus carries many Pentecostal broadcasts (De Witte 2011). In a similar vein, Kwaw Ansah dislikes Ghanaian and Nigerian video-movies that depict African tradition as the realm of dangerous powers. This type of movies is very popular, however, and attracts large audiences and thus TV Africa frequently shows them, alongside the epic genre of films described above that is much more to the station's liking.

\section{Conclusion}

The key concern in this article has been to describe and analyze the dynamics of heritage making, contestation, and re-styling in Ghana as the country shifted from a state-centrist model of media control and cultural politics towards neoliberal reforms and deregulation. Approaching heritage as a historically constituted arena with various players, we have discerned a remarkable shift from the state to the market in the field of heritage formation and signaled the emergence of new forms of marketdriven heritage design, as commercial producers and media entrepreneurs pick up where the state, in its role of guardian of cultural heritage, increasingly retreats. This shift entailed three significant trends with regard to the framing and designing of cultural pasts: from a national/Ghanaian framing to a transnational/Pan-African one (encompassing Ghana), from an emphasis on substantial cultural essence to style and design, and from a Pentecostal rejection of heritage as demonic power to acceptance of and pleasure in heritage as style.

Whereas the Sankofaism of the 1960 s to 1980 s represented a political, countercolonial expression of an African(ized) modernity, and grounded cultural authenticity in the ancestral past, what we see emerging today is a post-Sankofaism that places African heritage firmly within global neoliberalism and cosmopolitanism and looks for visual attraction as much as moral or political values. What the examples of epic video-films and TV Africa have shown is that cultural heritage becomes an urban style, with its design partly being mediated through global media and globalised imaginations of African culture and tradition. This new mode of heritage design deemphasizes cultural essence and substance in favor of visual aesthetics. Moving from, as it were, essence to appearance entails a process of disenchanting culture, through which cultural forms become broadly acceptable, yet risk being critiqued as shallow at the same time. While Pentecostal Christians tend to dismiss claims to cultural essence as a problematic invocation of spiritual power, they start appreciating heritage as design.

It might be tempting to interpret the shift from state to market, from essence to appearance, as a shift from an intellectualist emphasis on knowing about cultural heritage to an emotional emphasis on affect and sensory engagement with heritage. Indeed, emphasis on 'experience' and 'sensation' (in the double sense of the term) is a more general characteristic of contemporary commercialized entertainment. This is also evident in today's heritage industries where we discern a trend to fashioning heritage in such a way that people are invited to appropriate it on the level of experience. However, in our view it would be mistaken to confine the pivotal importance of modes of addressing the senses and invoking emotions to recent commercially driven modes of heritage making. 
Although the Ghanaian state's approach to heritage was indeed characterized by an emphasis on spreading knowledge about national cultural heritage, it was also meant to produce in citizens an emotional attachment to the nation. Therefore, we insist that the formation of heritage always implies an emotional and sensorial dimension that deserves special attention in scholarly analysis. The point is that in Ghanaian heritage dynamics we spot shifts in the mobilization of emotional registers, ranging from pride, to passionate rejection, to pleasure. Instilling pride in the citizens of the nation was the main concern of Sankofaism with its display of 'pomp and pageantry' and the celebration of the nation's 'rich and colorful heritage.' Next to teaching citizens about the wealth and moral value of Ghana's diverse cultural traditions, the state's concern was to stimulate a feeling of national pride and an emotional attachment to nation. This project, as we showed, was met with passionate rejection on the part of especially, Pentecostal - Christians, who feared that the celebration of heritage would conjure dangerous spiritual powers. They refuse to participate in such celebrations, and iconoclastic provocations testify to the deep negative emotions involved in the rejection of Sankofaism. Intriguingly, coded in terms of pleasure, the visually appealing display of culture as a lavish spectacle or a sophisticated design strips cultural heritage of its dangerous power and makes feelings of enjoyment possible. While the generation of pride remains important, as is expressed by TV Africa's slogan 'Truly African, Proudly Ghanaian,' it ties in much more with the global discourse and aesthetics of African/Black pride than with national pride.

While, for the sake of clarity, we have analyzed these different modes of framing and designing heritage as shifts, we do not take them as bringing about radical historical breaks. Rather, we understand the shifts as layers historically built up one over the other, and hence as co-existing, partly overlapping, and continually invoking each other. In the historically generated discursive and sensational field we have described, 'heritage' can thus mobilize the ancestral past in radically different, but interpenetrating ways. Herein lie the dynamics of heritage: given the ever-present possibility of evoking something else than is intended any presentation of cultural forms as heritage contains a fundamental instability.

\section{References}

Asamoah-Gyadu, Kwabena, 2005a. "Of Faith and Visual Alertness: The Message of "Mediatized" Religion in an African Pentecostal Context," Material Religion 1(3): 336-357.

-, 2005b.“'Christ is the Answer, What's the Question?’ A Ghana Airways Prayer Vigil and its Implications for Religion, Evil, and Public Space,” Journal of Religion in Africa 35(1): 93-117.

BeCKer, Heike, 2008. Negotiating Culture in Contemporary South Africa: Photographic SelfRepresentations from the Cape Flats. BAB Working Paper 2008: 3. Basel: Basler Afrika Bibliographien (BAB).

-, 2011. "Commemorating heroes in Windhoek and Eenhaha: Memory, Culture and Nationalism in Namibia, 1990-2010," Africa 81(4): 519-43.

Brosius, Christiane \& Karin M. Polit, 2011. "Introduction: Ritual, Heritage and Identity in a Globalised World," in Christiane Brosius \& Karin M. Polit (eds), Ritual, Heritage and Identity: The Politics of Culture and Performance in a Globalised World, 1-16. London, New York, New Delhi: Routledge. 


\section{African Heritage Design}

Coe, Cati, 2006. Dilemmas of Culture in African Schools: Youth, Nationalism, and the Transformation of Knowledge. Chicago: University of Chicago Press.

Comaroff, John and Jean Comaroff, 2009. Ethnicity, Inc. Chicago: University of Chicago Press.

De Jong, Ferdinand and Michael Rowlands (eds), 2007. Reclaiming Heritage: Alternative Imaginaries of Memory in West-Africa. Walnut Creek: Left Coast Press.

DE Witte, Marleen, 2001. Long Live the Dead! Changing funeral practices in Asante, Ghana. Amsterdam: Aksant Academic Publishers.

-, 2003. “Altar Media's Living Word: Televised Charismatic Christianity in Ghana," Journal of Religion in Africa 33(2): 172-202.

-, 2004. “Afrikania’s Dilemma: Reframing African Authenticity in a Christian Public Sphere". Etnofoor 17(1/2): 133-155.

-, 2005. 'Insight,' Secrecy, Beasts, and Beauty: Struggles over the Making of a Ghanaian Documentary on 'African traditional religion.' Postscripts 1(2/3): 277-300.

-, 2008. Spirit Media: Charismatics, Traditionalists, and Mediation Practices in Ghana. Ph.D. Dissertation, University of Amsterdam.

-, 2011. "Business of the Spirit: Ghanaian broadcast media and the commercial exploitation of Pentecostalism.” Journal of African Media Studies 3(2): 189-205.

Diawara, Manthia, 1992. African Cinema: Politics and Culture. Bloomington: Indiana University Press.

Ferguson, James, 1999. Expectations of Modernity: Myths and Meanings of Urban Life on the Zambian Copperbelt. Berkeley: University of California Press.

Gifford, Paul, 2004. Ghana's New Christianity: Pentecostalism in a Globalising African Economy. London: Hurst and Company.

Gotт, Suzanne, 2010. "The Ghanaian Kaba: Fashion That Sustains Culture,” in S. Gott and K. Loughran (eds), Contemporary African Fashion, 11-27. Bloomington: Indiana University Press.

Hasty, Jennifer, 2002. "Rites of Passage, Routes of Redemption: Emancipation Tourism and the Wealth of Culture." Africa Today 49(3): 47-76.

Haynes, Jonathan, 2000. Nigerian Video Films. Columbus: Ohio University Press.

Holsey, Bayo, 2008. Routes of Remembrance: Refashioning the Slave Trade in Ghana. Chicago: The University of Chicago Press.

Jorgensen, Anne-Mette, 2001. "Sankofa and Modern Authenticity and Ghanaian Film and Television," in M.E. Baaz and M. Palmberg (eds), Same and Other: Negotiating African Identity in Cultural Production, 119-142. Stockholm: Nordiska Afrikainsititutet.

Kirshenblatt-Gimblett, Barbara, 1998. Destination Culture: Tourism, Museums, and Heritage. Berkeley: University of California Press.

Lenz, Carola, 2006. Ethnicity and the Making of History in Northern Ghana. Edinburgh: Edinburgh University Press.

McCALL, John, 2007. “The Pan-Africanism We Have: Nollywood's Invention of Africa.” Filmint 28, 5(4): 92-97.

McCAskie, Tom, 2008. "Gun Culture in Kumasi,” Africa 78(3): 433-454.

Meyer, Birgit, 1998. "“Make a complete break with the past.' Memory and Post-colonial Modernity in Ghanaian Pentecostalist Discourse.” Journal of Religion in Africa 27(3): 316-349.

-, 1999a. Translating the Devil: Religion and Modernity among the Ewe in Ghana. IAL-Series. Edinburgh: Edinburgh University Press; Trenton, NJ: Africa World Press. 
-, 1999b. "Popular Ghanaian Cinema and 'African Heritage." Africa Today 46(2): 93-114.

-, 2002. "Christianity and the Ewe Nation: German Pietist Missionaries, Ewe Converts and the Politics of Culture." Journal of Religion in Africa 32(2): 167-199.

-, 2004. “'Praise the Lord...' Popular Cinema and Pentecostalite Style in Ghana's New Public Sphere.” American Ethnologist 31(1): 92-110.

-, 2005. "Mediating Tradition: Pentecostal Pastors, African Priests, and Chiefs in Ghanaian Popular Films," in Toyin Falola (ed.), Christianity and Social Change in Africa. Essays in Honor of J.D.Y. Peel, 275-306. Durham, NC: Carolina Academic Press.

-, 2010. "'Tradition and Colour at its best.' 'Tradition' and 'Heritage' in Ghanaian Video-movies." Journal of African Cultural Studies. Special issue on African Screen Media. 22(1): 7-23.

Meyer, Birgit, Herman Roodenburg, and Mattijs Van de Port, 2008. "Heritage Dynamics: Politics of Authentication and Aesthetics of Persuasion in Ghana, South Africa, Brazil and the Netherlands." NWO research proposal.

Probst, Peter, 2011. Osogbo and the Art of Heritage: Monuments, Deities, and Money. Bloomington: Indiana University Press.

SAul, Mahir and Ralph Austen (eds), 2010. Viewing African Cinema in the Twenty-First Century: Art Films and the Nollywood Video Revolution. Columbus: Ohio University Press.

SARpong, Peter, 1996. Libation. Accra: Anansesem Publications.

Schramm, Katharina, 2004. "Senses of Authenticity: Chieftaincy and the Politics of Heritage in Ghana." Etnofoor 17(1/2): 156-177.

-, 2010. African Homecoming: Pan-African Ideology and Contested Heritage. Walnut Creek: Left Coast Press.

Shipley, Jesse, 2009. "Aesthetics of the Entrepreneur: Afro-Cosmopolitanism, Rap, and Moral Circulation in Accra, Ghana," Anthropological Quarterly 82(3): 631-668.

ThalÉn, Oliver, 2011. "Ghanaian Entertainment Brokers: Urban Change, and Afro-Cosmopolitanism, with Neoliberal Reform." Journal of African Media Studies 3(2): 227-240.

Van den Bersselaar, Dmitri, 2007. The King of Drinks: Schnapps Gin from Modernity to Tradition. Leiden: Brill.

VAN DiJk, Rijk, 2001. "Contesting Silence: the Ban on Drumming and the Musical Politics of Pentecostalism in Ghana." Ghana Studies 4: 31-64.

Woets, Rhoda, 2011. What is this? Framing Ghanaian Art from the Colonial Encounter to the Present. Ph.D. Dissertation, VU University, Amsterdam. 